\title{
Asymmetry in Cognitive and Speech Development of Children: Dialogic Process in Intre- and Intrapsychological Aspects
}

\author{
Anna Petrova, and Nadezhda Sytina* \\ Volgograd State University, Foreign Language Department, Russia
}

\begin{abstract}
The current paper deals with correlation between cognitive and speech development of children from the socialization perspective. It relies on the assumption that children thinking and speech processes develop asynchronously. The material consists of the experimental results of pilot tests with the use of the associative method. The peculiarities of cognitive and speech development of infants, speaking different languages, are considered. The experimental evidence suggests that preschool-aged children understand adult's speech in a particular situation. The authors claim that children have better receptive language abilities rather than productive abilities. It is concluded that correlation between cognitive and speech development of children is connected with a dialogic process and mental activity on inter-and intrapsychological levels. The dialogic process shows that mental activity keeps its «quasi-social» character in intrapsychological aspect.
\end{abstract}

\section{Introduction}

In the late 1920 s and early 1930 s of the last century, psychology of speech, as a separate field, was developed in Russian and foreign psychologies. The roots of the separation go back to the concept of relation between speech and thinking within the theory of psychological and mental development (perception, attention, voluntary memory and etc.). Recent decades have seen different research perspectives on analyzing the problem of methods for studying correlation between cognitive development and speech process. With the respect to the stages of cognitive development, there is a question about the reliability of experimental tests in terms of verbal or nonverbal abilities. The purpose of the current paper is to study correlation between cognitive and speech development of children in performances of nonverbal tests with the follow-up commenting on their actions as requested by adults.

\subsection{Methodology in research}

Russian and foreign psychologists who dwell on the study of cognitive and speech development adhere to different research perspectives. For example, Piaget suggested that children's cognitive development should be examined with various tests including verbal ones which were used in investigating adult's speech [1]. According to Piaget, speech and language are the tools of thinking. Meanwhile, ontogenesis data indicate that children in early ontogenesis demonstrate the ability to perform mental operations. For example, they can classify objects based on their attributes when there are no nominations for these attributes in a child's speech.

In the Russian psychology, it was Uznadze who pointed out this fact. He performed an experiment on children, aged 6, involved in classifying objects. However, observing three-year old children, he found out only two cases of classification on the grounds related to objects' attributes. For other cases, children only provided words: "they are the same" or "different from these" [2]. Though the children did not produce the verbal attribute nominations, they provided co-speech gestures and words referring to the properties of the objects ("the same" or "different from these") [3]. Thus, deictic language supported by gestures (to represent the objects' properties) confirms the experimental results.

The experiment by Gorelov was conducted after Uznadze fifty years later. Within the group of three- year old children, the performance measure was with $10 \%$ up to $60 \%$ of positive results [4-5]. The experiment was completely nonverbal. The participants put the pieces into four boxes according to the target picture placed in the box. The language production task (to explain the choice) was performed with a deictic language and gestures as it was described by Uznadze.

There is considerable evidence to suggest that children thinking and speech processes develop asynchronously [6-7]. The verbal method of children's testing development is widely used in both theory and practice of children testing. The level of cognitive development is judged by the level of speech competence [8-9]. In some cases (signs of psychopathic and paranoid condition,

* Corresponding author: n.sityna@ volsu.ru 
child's schizophrenia), verbal tests determine pathology in cognitive development but not in all.

More than fifty years ago Luria and his colleague Yudovich accomplished the experimental research on cognitive and speech development observing two children aged 5 and 6 [10-11].

\subsection{Method}

Later the pilot experiment conducted together with Gorelov partly confirmed their findings. We considered the peculiarities of cognitive and speech development of German- and Russian-speaking children. Three groups of children participated in this study, young infants (age 02.5), infants (age 2.5-4.0) and preschoolers (age 4.0-7.0). The abilities were investigated by the association method. The experiment provided evidence that children demonstrate the ability to abstract from a particular situation and produce a verbal reaction to a presented verbal stimulus, including reaction-antonym as well as the ability to interact (age 5.0). The experiment, focused on the text perception among the given age group, helped to discover the difference between the ability to perceive, understand and produce the language according to the situational demands. Most of words learned by children are narrowed to one or two meanings of a word appeared in the adults' speech. Thus, children master surface structure quite well. In other words, understanding all the lexical units in a text does not mean understanding of the whole text. It suggests that an understanding of the situation is achieved only through social practice.

Our study bears on the question if standardized tests for measuring a child's level of speech development are reliable for intellectual development.

Let us examine the experimental results of the social and speech activity of the German and Russian speaking children aged 4.2-4.5.

The German speaking girl (4.2) demonstrates the features of a typical introvert. She is not talkative and inactive. The caregiver reports her poor speech development: she is able to understand almost everything but her speech is not expressive and emotional. According to the parents, the girl demonstrates the egocentric private speech (whispering), observed during a play. She receives two nonverbal tasks: a puzzle assembly task and labyrinth game. The girl is asked to connect the pieces of the puzzle to produce a copy according to the picture. She completes the task in 2 min.; the puzzle assembly without a prompt - in 5 min. Within the puzzle assembly assessment (puzzle finishing score and puzzle connection score), she has the same scores as other children. However, in the labyrinth task she demonstrates better results than other children and does a more complicated puzzle assembly fairly quickly. The language production task, when being asked to explain the choice of the pieces, was performed by the girl with simple segment structures. Within this method of testing, solving practical tasks, she demonstrates all necessary mental skills: analysis, synthesis and selfcorrection. Nevertheless, her speech development differs from that of the peers. Thus, she is in the need of stimulating the speech development.
The Russian-speaking boy (age 4.5) is active in communication with correct and emotional speech, supported by mimics and gesture. He demonstrates the enhanced verbal memory. The breathing pauses are short and filled with repeated words. When the experimenter asks him to describe the observed situation, he produces gesture information. The boy also addresses the interlocutor with a question without expecting any answer. In performing the labyrinth task, the boy demonstrates poor results as he cannot concentrate on the performance. Moreover, he does not listen carefully to the verbal instructions provided for him; as a result, the boy gets distracted, makes mistakes and feels disappointed. It is obvious that the high level of speech competence is combined with ineffective puzzle solving, requiring mental activity. These two cases (as well as others) show an uneven level of development in different activities.

\section{Results}

Summarizing our observations, we find it possible to describe the experimental results.

1. Undoubtedly, asymmetry is present in cognitive and speech development of both Russian- and Germanspeaking children.

1. When children begin to understand the adult's speech in particular situations, they demonstrate better perception ability rather than production ability. Acting out verbal stimuli presented as instructions or requests, preschoolers cannot describe their own actions.

2. Based on familiar situations and ideas of particular objects, children recognize the objects and reflect them in their "microworld" within their own cognitive capabilities. However, there is an obvious separation of thought from practical action.

3. On the other hand, imitating adults' speech, preschoolers demonstrate the specific skills to reproduce closely what they hear. The imitated words are placed in creative utterances. In other words, a child can produce a correct utterance without understanding its meaning. It may result in child quasi-communication.

4.5. Uneven relationship between speech and thought in ontogenesis manifests in a complex interaction of multi-directional skills and abilities.

Following Bachtin understanding of dialogic process, we can identify hidden dialogisms in the scene with the German-speaking girl as well as dialogic process in interand intrapsychological aspects.

Let us consider the scenes of the conversation involving verbal and nonverbal interaction between an English-speaking mother (M) and her child (C). They are engaged in a puzzle solving task (to put puzzle pieces together according to a picture depicting a car).

1) C: Oh-o-o. (C. looking at the picture and the puzzle pieces). Ah-a-a-a, where should I put this one? (C. is taking the black puzzle piece, looking at the picture and looking at the puzzle pieces)

2) M: Well, where should this particular piece go? (C. puts the black piece, which she is holding in the hand, back to the puzzle pieces; looking at the puzzle piece) 
3) M: Look at the picture of another car and then you will find the place. (C. is looking at the picture and then at the puzzle pieces; looking again at the picture and then at the puzzle pieces)

4) C: We-e-ll...(C. is looking at the target picture; looking at the car copy)

5) $C:$ I am looking.

6) $C: M-m-m$, the back piece is over there in that puzzle. (C. is pointing to the back puzzle piece in the picture)

7) $C:(C$. is looking at the puzzle pieces; looking at the target picture; taking the orange piece). Well, where to put the orange one?

8) M: Where is it in another car? (C. is looking at the target picture)

9) $C:$ It is here. (C. is pointing to the orange piece in the picture)

10) C: (looking at the pieces of the puzzle; taking the orange piece; looking at the picture). How ...where...there... (looking at the picture)

11)C: You...you ... the yellow piece comes this side ... $(C$. is pointing to the yellow piece in the target picture; looking at the yellow piece in his hand)

12)M: $O K$

While comparing these scenes, we can elicit important microgenetic stages in the child's indirect behavior. The first two scenes begin with the child's question about the place of the puzzle piece (utterances (1) and (7)) and the mother's response). She focuses the child's attention on the picture (utterances (2), (3) and (8)). In both scenes the child's question initiates the mother's response which in turn encourages the child's answer. The communication activity is performed within social interaction (interpsychological). But the third scene has difference from the very beginning. Firstly, the child does not ask a full question about the place of the puzzle piece (though she starts asking about it in utterance (10). Secondly, and what is more important, while looking at the picture after utterance (10), she organizes her thoughts in the response which appears in private dialogue (interpsychological aspect) [12].

The verbal and nonverbal child's behavior in these examples contains the information about the position of a particular puzzle piece in the picture. Moreover, utterances (6), (9) and (11) indirectly support communication aimed at solving the task (they are connected with studying the picture and searching the place of a piece). Despite the fact that utterance (11) is a part of activity in the intrapsychological aspect while the rest utterances belong to the interpsychological side, they have much in common: they represent responses to questions. At the same time, utterance (11) is a response to the self-question (asked by the child). We can observe this short question in utterance (10). The next scenes demonstrate only responses in social dialogue. There are no questions at all, even reduced questions.

We can partly illustrate the process of transmitting language and non-language knowledge in every day communication between a German-speaking mother (the right column) and her child (the left column); the first column shows a child's age (for example, 1.0 - 1(year) and 0 (months)) [13-14].
Table 1. Language and non-language knowledge transmitting process in ontogenesis.

\begin{tabular}{|c|c|c|}
\hline Age & $\begin{array}{l}\text { Child's initiative } \\
\text { utterances }\end{array}$ & Mother's responses \\
\hline 1.0 & Da! (Yea!) & $\begin{array}{l}\mathrm{Da} \text { is ein Schmetterling } \\
\text { (This is a butterfly) }\end{array}$ \\
\hline 1.6 & Due! (Here, this!) & $\begin{array}{l}\text { Ja, viele Kühe! }{ }^{2} \\
\text { (Yes, a lot of cows) }\end{array}$ \\
\hline 2.0 & $\begin{array}{l}\text { Da Eder nab } \\
\text { (Federn) (Yea, this } \\
\text { rooster doesn't } \\
\text { have feathers) }\end{array}$ & $\begin{array}{l}\text { Ja, da sind dem Hahn seine } \\
\text { Federn ab, weil er nicht } \\
\text { aufgepasst hat }{ }^{3} \text { (Yes, it } \\
\text { wasn't careful) }\end{array}$ \\
\hline 2.1 & $\begin{array}{l}\text { Das put } \\
\text { (It brk..) }\end{array}$ & $\begin{array}{l}\text { Das is kaputtgegangen } \\
\text { gestern, ja } \\
\text { (Yes, it was broken } \\
\text { yesterday) }\end{array}$ \\
\hline 2.3 & $\begin{array}{l}\text { Ich bin auf'n } \\
\text { Pferdchen gereit } \\
\text { (I have rode a } \\
\text { horsie) }\end{array}$ & $\begin{array}{l}\text { Geritten, reiten, geritten } \\
\text { (ridden, ride, ridden) }\end{array}$ \\
\hline 2.5 & $\begin{array}{l}\text { Das put-de-dang } \\
\text { (It sometimes } \\
\text { happens) }\end{array}$ & $\begin{array}{l}\text { Ja das passiert manchmal }^{6} \\
\text { (Yes, it sometimes } \\
\text { happens) }\end{array}$ \\
\hline 2.8 & $\begin{array}{l}\text { Ich hab' mal an } \\
\text { den Daumen weh- } \\
\text { e-tan (Once I had a } \\
\text { pain in my finger) }\end{array}$ & $\begin{array}{l}\text { Du hast dir an den Daumen } \\
\text { mal weh getan } \\
\text { (You had a pain in the } \\
\text { finger) }\end{array}$ \\
\hline 3.1 & $\begin{array}{l}\text { Wo is ausserhalb } \\
\text { von Belin? } \\
\text { (What is out of } \\
\text { Berlin?) }\end{array}$ & $\begin{array}{l}\text { He weisst du da wo's nich, } \\
\text { wo wo, wo die Stadt } \\
\text { aufhört, da sind plötzlich } \\
\text { keine Häuser mehr, dann } \\
\text { beginnt die Landschaft, da } \\
\text { kommen kleine Dörfer } \\
\text { (Well, it is where, where, } \\
\text { where the city ends, there } \\
\text { are no houses and the } \\
\text { countryside begins with } \\
\text { small villages }\end{array}$ \\
\hline 3.3 & $\begin{array}{l}\text { Ich, ich reite nach } \\
\text { Amerika } \\
\text { (I, I ride to } \\
\text { America) }\end{array}$ & $\begin{array}{l}\text { Du reitest über's Meer }{ }^{9} \\
\text { (You ride over the sea) }\end{array}$ \\
\hline
\end{tabular}

The upper indices in the right column represent the adult's responses and their functions:

1 - identifying a new object by introducing a new nomination;

2 - confirming a child's identification (plurals), premodelling plural by marking with the help of the indefinite pronoun viele (a lot of), implicit phonetic component - correction;

3 - confirming a child's interpretation of the situation, concept reference (information about the cause, causeand- effect relationships), implicit phonetic component correction;

4 - confirming the object's state after some actions, transmitting knowledge of time by including the adverb 
of time gestern (yesterday), implication phonetic component - correction;

5 - implicit grammar correction (knowledge of verb forms);

6 - confirming the interpretation of the object's state, transmitting knowledge of an ongoing situation (passieren (happen)) by including the adverbial modifier manchmal (sometimes);

7 - confirming the state of the situation by including self-expression (auf sich selbst);

8 - explaining the meaning of the adverb of place, transmitting knowledge of location;

9 - maintaining the play activity and transmitting geographical knowledge; implicit doubts about feasibility of the action.

Problem-solving activities optimize children's tendency to engage in private speech and provide "responses". Some questions arise if these utterances are responses in social dialogue. For this reason, we should consider the concept of dialogism. First of all, these utterances are responses because they are supported by actions. Moreover, the genetic origins of these "answers" on the intrapsychological level can be found in mental activity on the intrapsychological level. Information is transmitted from an adult to a child and vise verse, but adult's knowledge acts for a child as a tool of thinking which facilitates cognitive development of a child.

In order to provide insight into some aspects of interaction, one should consider Bachtin's dialogism. Bachtin's theory makes it possible to understand how utterances are interrelated [15]. In Bachtin's view, dialogism is characterized by the multiplicity of voices. The question is how a voice relates and interacts with those of other voices altering the meaning associated with each word. This approach makes us believe that mental activity keeps its quasi-social nature even in the intrapsychological aspect.

Vygotsky states that higher psychological functions stem from social interactions. This is maintained by the concept of the zone of proximal development. This concept relates to the difference between what a child can achieve independently and what a child can achieve with guidance and encouragement from a skilled partner [16].

The concept of the zone of proximal development was applied by Vygotsky to mental development and learning. The former implies that measuring the potential level of development is as important as the level of actual development. The latter suggests that a learning situation is more meaningful than actual development. Thus, Vygotsky's approach to interdependence between actual development and potential development focuses on interand intrapsychological aspects of mental activity. It emphases the genetic law of cultural development. On the other hand, these questions are included in the problem of individual socialization; in the case of ontogenesis this means the development of individual socialization [17].

\section{Conclusion}

Social environment, in which a child internalizes symbols, objects, places, things and their social functioning, encourages a child's effective adaptation to situational demands. A child realizes the novel position as one of the members in the community [18]. The dialogue "self-community" develops a relationship with others as the basic condition for human interpersonal relations and an individualization process.

Thus, shaping a social position is a dynamic process, as well as the result of a child's development in infancy. The transformation of the position depends on psychological development and social surrounding at each aged-related stage.

\section{References}

1. J. Piaget, Introduction. Genetic psychology (Moscow, 1967)

2. D.N. Uznadze, Psychology of set (Voronezh, 1997)

3. D.Yu. Gulinov, M.R. Zheltukhina, L.A. Shestak, G.G. Slyshkin, V.V. Katermina, L.D. Chervyakova. Modern Journal of Language Teaching Methods 8 (2), 159-173 (2018).

4. I.N. Gorelov, On ability to distinct, remember and classify objects when there are no subjective nominations for these objects, Problems of psycholinguistics (Moscow, 1975)

5. I.N. Gorelov, Selected works on psychology (Moscow, 2003)

6. U. Weber, Kognitive und kommunikative Aspekte des Spracherwerbs (Pädagogischer Verlag Schwann, Düsseldorf, 1975).

7. L.N. Rebrina, E.Yu. Malushko, Representation of the mnemic process of "memorization" in German: constant features, Advances in Social Science Education and Humanities Research (ASSEHR) 97, 233-238 (2017).

8. L. Gleitman, Linguistics: The Cambridge Survey 3 , 150-193 (1989).

9. R. Tracy, Sprachliche Strukturentwicklung: linguistische und kognitionspsychologische Aspekte einer Theorie des Erstspracherwerbs (Tübinge, Narr, 1991).

10. D.I. Slobin, Cognitive prerequisites for the development of grammar, Studies of Child Language Development, 175-276 (1973).

11. A.R. Luria, Language and consciousness (Moscow, 1998)

12. J. Wertsch, Voices of the mind. Social cultural approach to a mediated action (Harvard Un. Pr. Cambridge, 1991)

13. B. Reimann, Berliner Cochlear Implant Symposium 15/16, 11, Berlin, 1-10 (2002).

14. E. Malushko, O. Maletina, V. Lizunkov, V. Tsybaneva, International Multidisciplinary Scientific Conferences on Social Sciences and Arts, 481-487 (2016)

15. M.M. Bachtin, Collected works in seven volumes 5 (Russian dictionaries, Moscow, 1996). (In Russian)

16. L.S. Vygotsky, Thinking and speech (Moscow, 1996) 
17.E.V. Bobyreva, O.A. Dmitrieva, M.R. Zheltukhina, M.V. Busygina, Advances in Social Science, Education and Humanities Research (ASSEHR) 97, 52-56 (2017).

18. M.A. Suzdalova, V.G. Lizunkov, E.Yu. Malushko, N.A. Sytina, V.E. Medvedev, The European Proceedings of Social \& Behavioural Sciences EpSBS XIX, 450-455 (2017). 